\title{
Discussion on Reinforcement Mechanism and Construction Technology of Pressurized Vacuum Preloading
}

\author{
ZHUGE Ai-jun ${ }^{1234 *}$ \\ ${ }^{1}$ Tianjin Port Engineering Institute Ltd. of CCCC First Harbor Engineering Company Ltd., Tianjin, 30222 China; \\ ${ }^{2}$ Key laboratory of port geotechnical engineering, ministry of communications, PRC Tianjin, 30222 China; \\ ${ }^{3}$ Key laboratory of port geotechnical engineering of Tianjin, Tianjin, $30222 \mathrm{China}$; \\ ${ }^{4}$ CCCC First Harbor Engineering Company Ltd., Tianjin, 30222 China;
}

\begin{abstract}
Based on the basic theory of vacuum preloading, this paper proposes an good effect of pressurized vacuum preloading in which the high pressure gas results in tiny cracks between the air pressurized pipe and band drain. Therefore additional drainage paths are introduced to improve the permeability of soil and accelerate soil consolidation. But field tests show that the advantages of pressurized vacuum preloading are not obvious compared with conventional vacuum preloading, and the soil settlement, soil properties and vane shear strength are slightly lower than those by conventional vacuum preloading. The vacuum pressure transmission is analysed in the air pressurized pipe and band drain as well as the dissipation of pore water pressure in the soil during the pressurization process, it is concluded that the unsatisfactory reinforcement effect is mainly due to the sealing problem between the top of the air pressurized pipe and the sand cushion, and the overlap problem between the booster pipe and band drain.
\end{abstract}

\section{Introduction}

In recent years, there were some problems that have plagued engineers during vacuum preloading and reinforcement for soft soil ground. For example, after the reinforcement, $3 \mathrm{~m}-5 \mathrm{~m}$ in the lower part of the soil layer is formed to a " bottleneck of lower strength " or "clogging of the band drain" during the reinforcement process [1]. In order to solve the above problems, Jin et al. [2] proposed a pressurized vacuum preloading method. This method is setting a pressure boosting pipe in the soil to increase the pressure difference between the band drain and the surrounding soil, which is improving the reinforcement effect of the vacuum preloading. Yan et al. [3] proposed that the introduction of controllable airflow during the vacuum preloading process can improve the drainage effect of the soil and accelerate the consolidation process of the soil. Lei et al. [4] carried out microstructural testing of the ultra-soft soil under dredging by means of electron microscopy (SEM) and mercury intrusion test (MIP). It is proved from the microscopic point that the pressurized vacuum preloading effect is better than the ordinary vacuum preheating. Shi et al [5] conducted an laboratory model test of pressurized vacuum preloading to compare the settlement, pore pressure cumulative dissipation and strength index, and measured the real-time variation of pore pressure during the pressurization process. In terms of engineering application, Lin et al. [6] combined with the Zhuhai West Station foundation treatment project, proved that the Pressurized vacuum preloading can greatly increase the settlement during the reinforcement period and achieve better soft foundation treatment. The literature [7-9] also introduces the application of pressurized vacuum preloading in many projects from different viewpoints.

In summary, although the laboratory contrast test has proved that the pressurized vacuum preloading is better than the ordinary vacuum preloading, application of project examples is necessary to evaluate the reinforcement effect of pressurized vacuum preloading.

\section{Preliminary study on reinforcement mechanism}

Vacuum preloading increases the effective stress by reducing the pore water pressure in the soil while the total stress remains substantially unchanged. The process of vacuum preloading is actually the process of continuously transforming pore water pressure into effective stress on the soil skeleton ${ }^{[10,11]}$. The main factors of affecting the vacuum preloading reinforcement effect are reinforcement load, soil index and drainage conditions.

(1) From the aspect of reinforcement load, the pressurized vacuum preload introduces high pressure gas during the pressurized construction process, which increases the pressure difference between the pressurization pipe and the band drain, thereby accelerating the water seepage speed and accelerating the water in the soil. Theoretically the boosting can improve

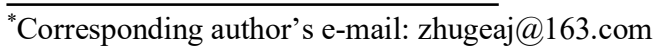


the reinforcement effect. However, the pressurized vacuum preloading process is only intermittently supercharged in the late stage of vacuum preloading (generally lasting $10-20 \mathrm{~d}$, daily pressurization time being $2 \mathrm{~h}-4 \mathrm{~h}$ ), and the cycle of boosting is very short. Therefore, its effect is limited since the duration is relatively short compared with whole of the reinforcement period $(120-200 \mathrm{~d})$.

(2) From the perspective of soil physical and mechanical indexes, the soil strength, deformation index and permeability are closely related. The permeability of soil is directly related to the rate of soil consolidation. Many scholars [12] found that the reinforcement mechanism of cement-powdered mixing piles can cause tiny cracks in the soil by applying high-pressure gas to the soil during the construction process. The cracks can provide drainage paths for excess pore water pressure to dissipation fast. If the pressurized vacuum preloading can cause cracks in the surrounding soil, the permeability coefficient of the foundation soil can be improved to a certain extent. As a result, the consolidation rate of the foundation soil is accelerated, thereby improving the reinforcement effect of foundation.

(3) From the viewpoint of the drainage conditions, the drainage layer is basically identical or similar in a improvement area. If the drainage conditions are the same when the band drain is set with the same depth and spacing, the drainage conditions are basically considered to be identical.

Therefore, the reinforcement mechanism of the pressurized vacuum preloading should be: in the process of vacuum preloading, by introducing high pressure gas, lots of tiny cracks are generated between the booster pipe and the band drain to form additional drainage channels and improve the permeability of soil. As a result, the permeability improves the drainage consolidation and thus the reinforcement effect.

\section{Field comparison test}

\subsection{Test area}

In order to compare the reinforcement effect, three vacuum preloading reinforcement zones were designed, i.e. the pressurized vacuum preloading zone (Zone 1) and ordinary vacuum preloading zones (Zone 2 and Zone 3 ). The main reinforcement parameters of each reinforcement zone are shown in Table 1.

Table 1 Main reinforcement parameter table of each reinforcement zone

\begin{tabular}{|c|c|c|c|}
\hline \multicolumn{2}{|c|}{ Vacuum preloading parameter } & $\begin{array}{c}\text { Zone } 1 \\
\text { Pressurized vacuum } \\
\text { preloading }\end{array}$ & $\begin{array}{c}\text { Zone } 2 / \text { Zone } 3 \\
\text { Ordinary vacuum preloading }\end{array}$ \\
\hline \multicolumn{2}{|c|}{ Dimensions(m) } & $195 \times 120$ & $195 \times 145$ \\
\hline \multirow{3}{*}{ Cushion } & Material & Sand & Sand \\
\hline & Thickness(m) & 0.6 & 0.6 \\
\hline & $\operatorname{Depth}(\mathrm{m})$ & 25 & 25 \\
\hline \multirow{4}{*}{ Band drain } & $\operatorname{Spacing}(\mathrm{m})$ & 0.8 & 0.8 \\
\hline & Arrangement & square & square \\
\hline & Type & Anti-clogging integral board & Anti-clogging integral board \\
\hline & Link method & Straight & Straight \\
\hline \multirow{3}{*}{$\begin{array}{l}\text { Booster } \\
\text { pipe }\end{array}$} & $\operatorname{Depth}(\mathrm{m})$ & 5 & 1 \\
\hline & $\operatorname{Spacing}(\mathrm{m})$ & 2.4 & l \\
\hline & Arrangement & square & / \\
\hline
\end{tabular}

artificial dredger fill layer (1-1 layer) in the pressurized

\subsection{Geological conditions}

The main physical and mechanical indexes of each soil layer in the test zones are shown in Table 2. As can be seen from Table 2, The geological conditions of the vacuum preloading reinforcement area are slightly better than the conventional vacuum preloading area.

Table 2 Main physical and mechanical indexes of each soil layer

\begin{tabular}{|c|c|c|c|c|c|c|c|c|}
\hline \multirow[t]{2}{*}{ Zone number } & \multirow[t]{2}{*}{$\begin{array}{l}\text { Soil } \\
\text { layer }\end{array}$} & $w$ & $\rho$ & $e$ & $I_{\mathrm{P}}$ & $I_{\mathrm{L}}$ & $a_{1-2}$ & $E_{\mathrm{s} 1-2}$ \\
\hline & & $\%$ & $\mathrm{~g} / \mathrm{cm}^{3}$ & -- & $\%$ & -- & $\mathrm{MPa}^{-1}$ & $\mathrm{MPa}$ \\
\hline Pressurized vacuum & $1-1$ & 99.8 & 1.47 & 2.732 & 24.9 & 3.1 & & \\
\hline preloading (Zone 1) & $1-2$ & 72.4 & 1.58 & 1.992 & 32.7 & 1.4 & 1.78 & 1.76 \\
\hline Ordinary vacuum & $2-1$ & 119.0 & 1.41 & 3.258 & 24.9 & 3.9 & & \\
\hline preloading (Zone 2) & $2-2$ & 71.0 & 1.56 & 2.003 & 30.8 & 1.5 & 1.75 & 1.74 \\
\hline Ordinary vacuum & $3-1$ & 112.2 & 1.45 & 3.014 & 26.1 & 3.4 & & \\
\hline preloading (Zone 3) & $3-2$ & 70.4 & 1.58 & 1.963 & 31.3 & 1.4 & 2.15 & 1.42 \\
\hline
\end{tabular}




\subsection{Main construction process}

The main differences between pressurized vacuum preloading and ordinary vacuum preloading are: (1)After the plastic band drain is installed, the booster pipeline is arranged; (2)When the duration of vacuum pre-pressure reaches $103 \mathrm{~d}$, air pressurization starts and continue for $18 \mathrm{~d}$, and the boost pressure is kept between $600 \mathrm{kPa}$ and $800 \mathrm{kPa}$ (at the outlet of the air compressor). Then the vacuum is continued until unloading.

During the vacuuming period, the vacuum pressure in each reinforcement zone is maintained at about $85 \mathrm{kPa}$. When the degree of consolidation meets $85 \%$, and the settlement rate meets the requirement of less than 2.0 $\mathrm{mm} / \mathrm{d}$, the unloading is performed. It is about $220 \mathrm{~d}$ of vacuum preloading for each reinforcement zone.

\subsection{Monitoring results}

The measurement results of surface settlement in each reinforcement area are shown in Table 3 . The settlement process is shown in Fig. 1 and Fig.2. As it can be seen from Fig.1 and Fig. 2, The surface settlement value during the pressurized vacuum preloading reinforcement process is slightly smaller than the ordinary vacuum preloading, and the settlement rate before and after the pressurization is close to the ordinary vacuum preloading.

Table 3 Summary of observation results of each reinforcement area

\begin{tabular}{ccccccc}
\hline $\begin{array}{c}\text { Vacuum } \\
\text { preloading } \\
\text { parameter }\end{array}$ & $\begin{array}{c}\text { Zone } \\
\text { number }\end{array}$ & $\begin{array}{c}\text { Settlement in } \\
\text { drain board } \\
\text { setting } \\
\text { period(mm) }\end{array}$ & $\begin{array}{c}\text { Settlement in } \\
\text { vacuum load } \\
\text { applying } \\
\text { period(mm) }\end{array}$ & $\begin{array}{c}\text { Total } \\
\text { settlement(mm) }\end{array}$ & $\begin{array}{c}\text { Settlement } \\
\text { developing rate } \\
(\mathrm{mm} / \mathrm{d})\end{array}$ & $\begin{array}{c}\text { Comprehensive } \\
\text { consolidation } \\
\text { degree }(\%)\end{array}$ \\
\hline $\begin{array}{c}\text { Pressurized } \\
\text { vacuum } \\
\text { preloading } \\
\text { Ordinary } \\
\text { vacuum }\end{array}$ & Zone 1 & 558 & 2093 & 2651 & 1.9 & 86.8 \\
$\begin{array}{c}\text { preloading } \\
\text { Ordinary } \\
\text { vacuum } \\
\text { preloading }\end{array}$ & Zone 2 3 & 615 & 2615 & 3230 & 1.8 & 86.2 \\
\hline
\end{tabular}

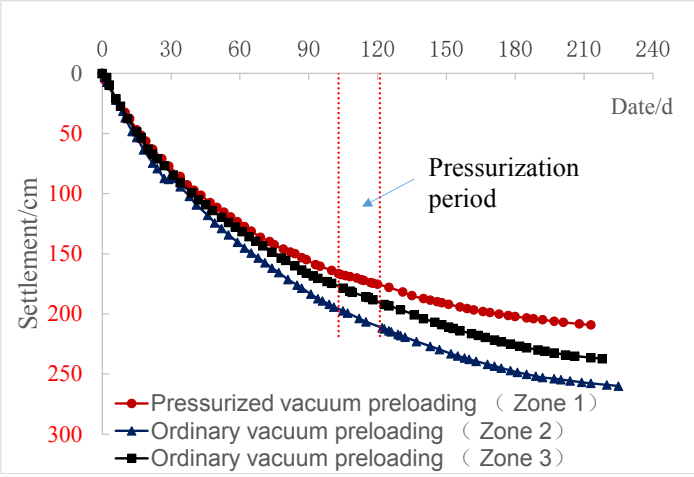

Figure 1. Curves of settlement versus time

In order to understand the pressure transmission inside the supercharger pipe and the band drain, a typical section is selected for analysis. The layout of the

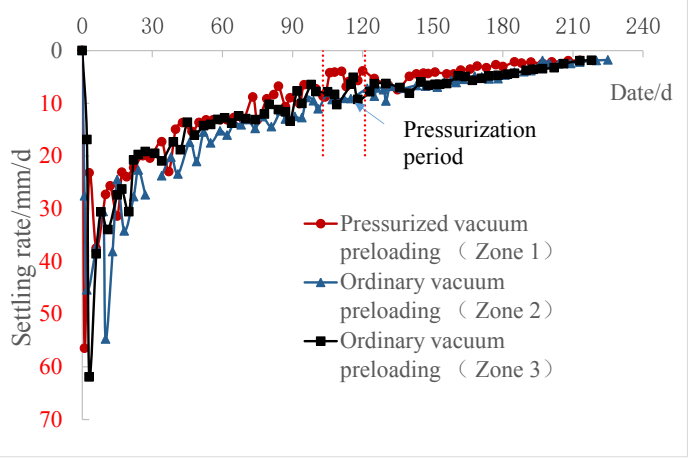

Figure 2. Curves of settlement rate versus time

monitoring instrument in this section is shown in Figure 3. The cross-sectional layout of the monitoring instrument is shown in Figure 4.

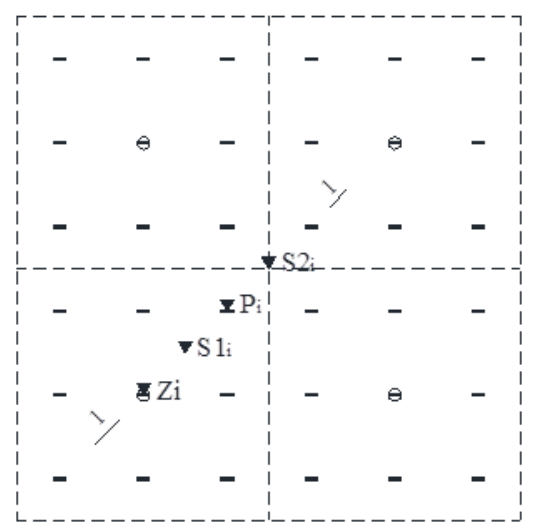

Legend:

Zone

- Drainage board

$\ominus$ Booster tube

(The upper part is a booster tube, the lower part is a drain plate)

$3 \mathrm{Zi}$ Pressure monitoring point in the booster tube

I $\mathrm{Pi}$ Pressure monitoring point in the drainage board

$\nabla_{\mathrm{Si}}$ Pore water pressure observation point in the foundation

Figure 3. The layout of the monitoring instrument 


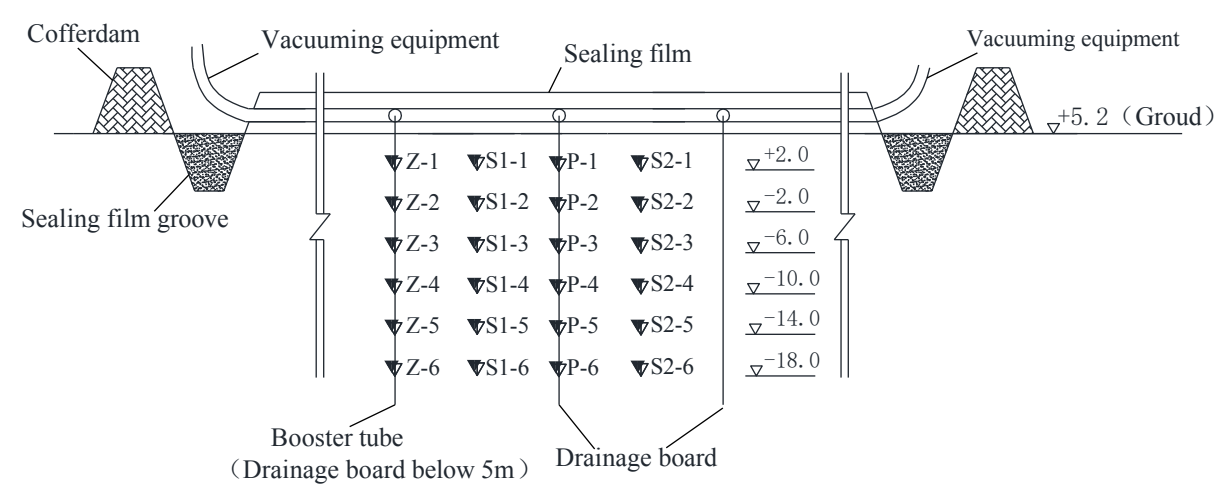

Figure. 4 The cross-sectional layout of the monitoring instrument

The curve of the vacuum pressure versus time in the pressurization pipe and the band drain are shown in Fig. 5 and Fig. 6. As it can be seen from Fig.5 and Fig.6, During the vacuum preloading, the vacuum pressure gradually increases with time, and then remains basically stable. During the pressurization, the vacuum pressure in the pressurization pipe and the band drain drops about $20 \mathrm{kPa}$ to $40 \mathrm{kPa}$ on average, and the vacuum pressure can be basically restored after the pressurization is completed.

When analysing the vacuum pressure, we select the pressures of pre- and post-pressurization, and draw the curves of vacuum pressure versus depth as shown in Fig.7. As it can be seen from Fig. 7, regardless of the pressurization, the vacuum pressure value in the pressurization pipe is lower than that in the adjacent band drain by about $20 \mathrm{kPa}$, and the vacuum pressure is slightly attenuated along the depth direction.

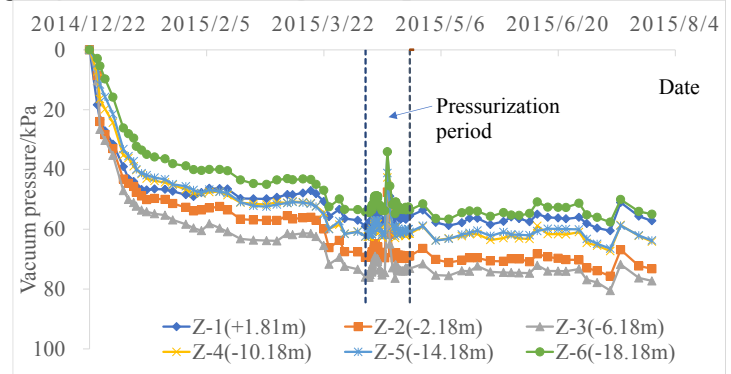

Figure 5. Curves of vacuum pressure versus time in pressurization

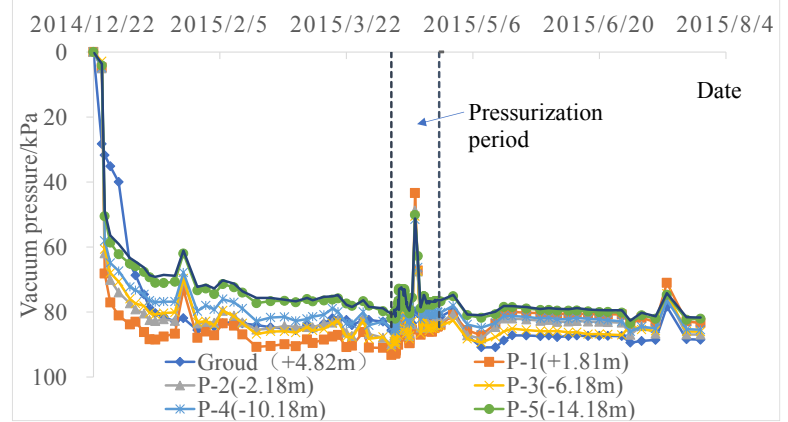

Figure.6 Curves of vacuum pressure versus time in band drain

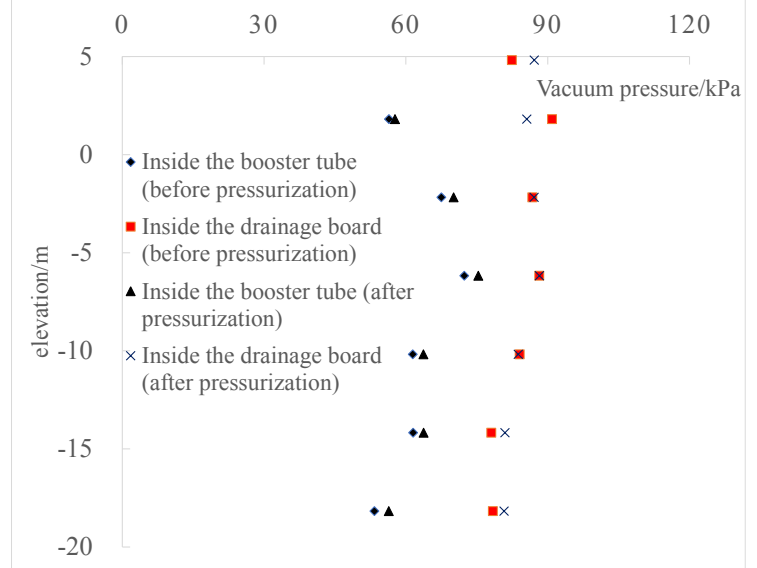

Figure.7 Curve of vacuum pressure versus depth for different reinforcement processes

In the process of pressurization, the pore water pressure is monitored. The curves of pore water pressure versus time in the foundation is shown in Fig. 8 and Fig. 9. During the whole pressurization process, the pore water pressure dissipated smoothly. After pressurization, the pore water pressure continued to dissipate with the previous dissipating trend, and the dissipation variation due to pressurization was not obvious.

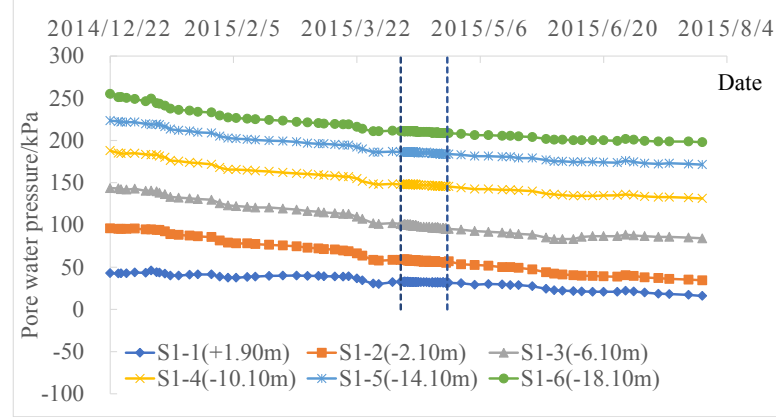

Figure.8 Curves of pore water pressure versus time (S1) 


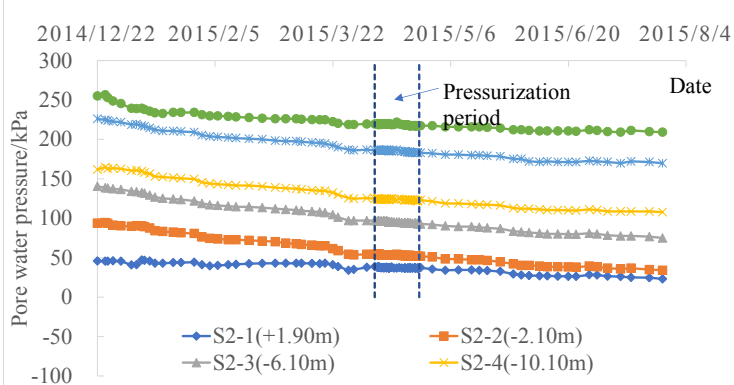

Figure.9 Curves of pore water pressure versus time (S2)
The main indexes of the soil under different reinforcement methods are shown in Table 4 . It can be seen from Table 4 that the foundation soils improved by these two reinforcement methods have been improved. Due to the relatively better condition of the ground before reinforcement, the improvement by the pressurized vacuum preloaded is slightly lower.

Table 4 Variation of soil characteristics of pre- and post-reinforcement

\begin{tabular}{|c|c|c|c|c|c|c|}
\hline \multirow[t]{2}{*}{$\begin{array}{l}\text { Reinforcement } \\
\text { method }\end{array}$} & \multicolumn{3}{|c|}{ Soil layer number } & \multirow{2}{*}{$\begin{array}{l}w \\
\%\end{array}$} & \multirow{2}{*}{$\begin{array}{c}\rho \\
\mathrm{g} / \mathrm{cm}^{3}\end{array}$} & \multirow{2}{*}{$\begin{array}{l}e \\
-- \\
\end{array}$} \\
\hline & \multirow{3}{*}{\multicolumn{2}{|c|}{ Before reinforcement }} & & & & \\
\hline \multirow{6}{*}{$\begin{array}{l}\text { Pressurized vacuum } \\
\text { preloading (Zone } 1)\end{array}$} & & & $1-1$ & 99.8 & 1.47 & 2.732 \\
\hline & & & $1-2$ & 72.4 & 1.58 & 1.992 \\
\hline & \multirow{2}{*}{\multicolumn{2}{|c|}{ After reinforcement }} & $1-1$ & 58.1 & 1.67 & 1.621 \\
\hline & & & $1-2$ & 63.1 & 1.63 & 1.773 \\
\hline & \multirow{2}{*}{\multicolumn{2}{|c|}{ Improvement ratio }} & $1-1$ & $41.8 \%$ & $13.5 \%$ & $40.7 \%$ \\
\hline & & & $1-2$ & $13.0 \%$ & $2.9 \%$ & $11.0 \%$ \\
\hline \multirow{6}{*}{$\begin{array}{c}\text { Ordinary vacuum } \\
\text { preloading (Zone 2) }\end{array}$} & \multirow{2}{*}{\multicolumn{2}{|c|}{ Before reinforcement }} & $2-1$ & 119.0 & 1.41 & 3.258 \\
\hline & & & $2-2$ & 71.0 & 1.56 & 2.003 \\
\hline & \multirow{2}{*}{\multicolumn{2}{|c|}{ After reinforcement }} & $2-1$ & 57.4 & 1.67 & 1.605 \\
\hline & & & $2-2$ & 62.3 & 1.63 & 1.744 \\
\hline & \multirow{2}{*}{\multicolumn{2}{|c|}{ Improvement ratio }} & $1-1$ & $51.8 \%$ & $18.4 \%$ & $50.7 \%$ \\
\hline & & & $1-2$ & $12.3 \%$ & $4.7 \%$ & $12.9 \%$ \\
\hline \multirow{6}{*}{$\begin{array}{c}\text { Ordinary vacuum } \\
\text { preloading (Zone } 3 \text { ) }\end{array}$} & \multirow{2}{*}{\multicolumn{2}{|c|}{ Before reinforcement }} & $3-1$ & 112.2 & 1.45 & 3.014 \\
\hline & & & $3-2$ & 70.4 & 1.58 & 1.963 \\
\hline & \multirow{2}{*}{\multicolumn{2}{|c|}{ After reinforcement }} & $3-1$ & 58.0 & 1.69 & 1.602 \\
\hline & & & $3-2$ & 62.1 & 1.64 & 1.736 \\
\hline & \multirow{2}{*}{\multicolumn{2}{|c|}{ Improvement ratio }} & $1-1$ & $48.3 \%$ & $16.5 \%$ & $46.8 \%$ \\
\hline & & & $1-2$ & $11.8 \%$ & $3.9 \%$ & $11.6 \%$ \\
\hline \multirow{2}{*}{\multicolumn{7}{|c|}{$\begin{array}{l}\text { he results of the vane shear strength tests are shown } \\
\text { ble } 5 \text {. As can be seen from Table } 5 \text {, After vacuum } \\
\text { ading reinforcement, the vane shear strength of the } \\
\text { dation soil has been greatly improved, especially for }\end{array}$}} \\
\hline & & & & & & \\
\hline Reinforcement method & Soil layer & $\begin{array}{l}\text { Zone } \\
\text { number }\end{array}$ & $\begin{array}{l}\text { Before } \\
\text { reinforcement } \\
(\mathrm{kPa})\end{array}$ & & $\begin{array}{l}\text { fter } \\
\text { cement } \\
\mathrm{Pa})\end{array}$ & $\begin{array}{l}\text { Improvement } \\
\text { value } \\
(\mathrm{kPa})\end{array}$ \\
\hline $\begin{array}{c}\text { Pressurized vacuum } \\
\text { preloading }\end{array}$ & & $1-1$ & 2.3 & & 3.4 & 11.1 \\
\hline $\begin{array}{l}\text { Ordinary vacuum } \\
\text { preloading }\end{array}$ & $\begin{array}{l}\text { Filling soft } \\
\text { soil }\end{array}$ & $2-1$ & 2.0 & & 5.4 & 13.4 \\
\hline $\begin{array}{l}\text { Ordinary vacuum } \\
\text { preloading }\end{array}$ & & $3-1$ & 2.1 & & 5.5 & 13.4 \\
\hline $\begin{array}{l}\text { Pressurized vacuum } \\
\text { preloading }\end{array}$ & & $1-2$ & 26.3 & & 7.8 & 11.4 \\
\hline $\begin{array}{c}\text { Ordinary vacuum } \\
\text { preloading }\end{array}$ & $\begin{array}{c}\text { Marine } \\
\text { sedimentary }\end{array}$ & $2-2$ & 28.2 & & 9.6 & 11.4 \\
\hline $\begin{array}{l}\text { Ordinary vacuum } \\
\text { preloading }\end{array}$ & soil & $3-2$ & 28.2 & & 9.4 & 11.2 \\
\hline
\end{tabular}




\section{Discussion on construction technology}

In summary, compared with preloading compared with ordinary vacuum preloading, the advantages of pressurized vacuum is not obvious during this field test. The pressurized vacuum preloading settlement, the change of soil index and the vane shear strength is slightly lower than these obtained by the ordinary vacuum preloading. During the pressurization period, neither the pore water pressure dissipation changes, nor the pore water pressure reading increased rapidly during the pressurization process. Moreover, when the pressurization stops, the pore water pressure did not show any change. This is inconsistent with the phenomenon and conclusion from pressurized vacuum preloading test conducted in the laboratory. It is analysed that these unexpected phenomenon is caused by the construction technology.

(1) The position of the pressurization pipe is located in the canter of the 9 band drains (as shown in Fig.3). Usually, after the drain plate is installed, a pressurization pipe of about $5 \mathrm{~m}$ is manually inserted, and the pressurization pipe is linked to the drain plate. Since the pressurization pipe and the band drain are also involved in vacuuming, the linkage will inevitably affect the vertical transfer of the vacuum pressure. Although the number of pressurization pipes in the entire reinforcement zone is relatively small, it will also have an impact on the overall foundation reinforcement effect.

(2) The upper part of the pressurization pipe adopts a closed air compressor air pipe of about $2 \mathrm{~m}$ (diameter 8 $\mathrm{mm}$ ). After the pressurization pipe is installed, the hole is sealed by a cohesive soil. The quality of the sealing directly affects the path of pressure transmission. During the pressurization process, the pore water pressure dissipation tendency did not change, but the band drain had a vacuum pressure drop synchronously with the pressurization pipe, indicating that the pressure was not transmitted horizontally during the pressurization process. Instead, it is transferred to the adjacent plastic drain through a horizontal drain cushion. When the hole sealing quality is not good, it will cause the sealing film to rise, which will cause the vacuum preload to fail.

\section{Conclusion}

Based on the basic principle of drainage consolidation method, this paper analyses the possible mechanism of pressurized vacuum preloading. The reinforcement effect of pressurized vacuum preloading and ordinary vacuum preloading was compared by field test. In the test, monitoring is performed on surface settlement, dissipation of the pore water pressure and the vacuum pressure transmission in the pressurization pipe and the band drain during the pressurization. After comparative analysis, the following conclusions are drawn:

(1) During the pressurization process, the pressure is increased difference between the pressurization pipe and the band drain. Compared with the entire reinforcement period (120 d to $200 \mathrm{~d}$ ), the pressurization duration is very short, and the pressurization effect is minimal. The ideal effect of pressurized vacuum preloading should be to create a small drainage path between the pressurization pipe and the band drain by introducing high pressure, improve the permeability of the soil, and accelerate the drainage consolidation.

(2) In view of the difference between laboratory tests and field tests, pressurized vacuum preloading also requires appropriate improvements to the construction process, especially between the top of the pressurization pipe and the drainage sand cushion, and between the pressurization and the drainage problem.

(3) At present, the timing and duration of pressurization, the magnitude of pressure and the control criteria are currently mainly based on past experiences. Due to the large difference in cohesion and permeability of different soils, the micro-cracks condition is different for the formation in the soil. It is recommended to carry out relevant experimental research work in the future.

(4) In the pressurized vacuum preloading construction process, in addition to the traditional monitoring items, the vacuum pressure inside the pressurization pipe, the vacuum pressure in the band drain should be monitored to understand the vacuum pressure transmission and soil consolidation in time for a purpose of analysis of reinforcement effect.

\section{References}

1. ZHENG Ai-rong, YIN Zi-qiang, WANG Shi-ning. Performance of plastic drain board after soft soil reinforcement $[\mathrm{J}]$. China Harbour Enmineering, 2019,39(04):33-36.

2. JIN Ya-wei, JIN Ya-jun, JIANG Jun-nan et al. Treatment using vacuum preloading with air pressure boosted in soft foundation ore railing mud [P]. China, 200820160080.7, 2009-07-15

3. YAN Shu-wang, ZHANG Li-li, SUN Li-qiang \& JI Yu-cheng. Experimental study on accelerating drainage method by introducing airflow into vacuum preloading [J]. Highway Traffic Technology (Application Technology Edition),2011,7(01):30$33+46$.

4. LEI Hua-yang, HU Yao, LEI Shang-hua, QI Zi-yang, \& XU Ying-gang. Analysis of microstructure characteristics of air-booster vacuum preloading for ultra-soft dredger fills [J]. Rock and Soil Mechanics ,2019(S1):1-9

5. SHI Li, HU Dong-dong, CAI Yuan-qiang, PAN Xiao-dong, \& SUN Hong-lei. Preliminary study on real-time response and reinforcement mechanism of Pressurized vacuum preloading and dredging [J]. Rock and Soil mechanics,2020(01):1-10

6. YANG Zi-jing, YU Jing, LIU Hui, JIN Ya-wei \& JIN Ya-jun. Pressurized vacuum pre-compacting technology[J]. Railway Standard Design, 2011(08): 26-31.

7. MA Yong-zheng, SHENG Chu-gen, CAI Ke-jian, WANG Kai-tai, \& SONG Xiao-wen. Study on soft 
soil foundation treatment by air-boosted vacuum preloading at coastal landfill site $[\mathrm{J}]$. China Harbour Enmineering,2016,36(12):29-34.

8. WU Song-hua. Field test on newly blown fill soil reinforced by pressurized vacuum pre-compacting [J]. Port \& Water Engineering,2018(09):181-185.

9. SHEN Yu-peng, FENG Rui-lin, ZHONG Shun-yuan \& LI Zhi. Research on optimization design of Pressurized vacuum preloading in railway station site treatment [J]. Journal of the Railway, 2012, 34(04): 88-93.

10. GAO Zhi-yi. Analysis on mechanics of vacuum preloading method $[\mathrm{J}]$. Geotechnical Engineering, 1989(04): 45-56.

11. GAO Zhi-yi. Theory and practice of vacuum preloading [M] Beijing: People's Communications Publishing Co., Ltd. 2015:22-26.

12. HAN Wen-jun, LIU Song-yu \& ZHANG Ding-wen. Experimental study of pneumatic fracturing effect in soil under overburden load $[\mathrm{J}]$. Rock and Soil Mechanics, 2011, 32(07): 1951-1956. 